Maritime disputes and seafood regimes: A broader perspective on fishing and the Philippines-China relationship

Michael Fabinyi

Faculty of Arts and Social Sciences, University of Technology Sydney

Postal address: PO Box 123, Broadway, New South Wales 2007, Australia

Email: michael.fabinyi@uts.edu.au

Phone: 61295142308

7953 words 


\title{
Maritime disputes and seafood regimes: A broader perspective on fishing and the Philippines-China relationship
}

\begin{abstract}
In much discussion surrounding the relationship between maritime disputes and fisheries resources, emphasis is given to the role of fisheries resources as a driver of the dispute or how states use fishing to further their interests through territoriality. Yet a narrow focus on maritime disputes obscures the broader ways in which fishing contributes to interstate relationships. This paper uses a political ecology and food regimes approach to demonstrate how seafood flows between the Philippines and China represent power relations. China exports a significant volume of low-value small fish and molluscs from its distant water fishery. The Philippines exports low numbers of high-value reef fish. Current Chinese aquaculture investments are minimal. Poaching forms another component of this seafood regime, which is marked by environmental unsustainability and unequal relations between the Philippines and China. This analysis highlights the value of seeing fishing and fishery resources as constitutive of a broader politicised environment.
\end{abstract}

Keywords: fisheries conflict; maritime dispute; China; Philippines; food regime; seafood

\section{Introduction}

Unresolved maritime disputes play an increasingly important role in international relations. In recent years, such disputes have intensified, driven by the progressive institutionalisation of the United Nations Convention on the Law of the Sea since the 1980s, increased interest in natural resource exploitation and expansion of maritime trade (Fravel, 2014). The role of fishing and fishery resources in maritime disputes has become a common theme for analysts (Song, 2015). One stream of literature has emphasised the value of fishery resources in disputed waters, highlighting their role as a material, economic factor motivating state actors to claim sovereignty (e.g., Schofield, Sumaila \& Cheung, 2016). A related thread has focused on how state actors use the fishing industry for political gain, promoting fishing to increase state authority over contested spaces through territorialisation (Erickson \& Kennedy, 2015; 
Rasmussen \& Lund, 2018). This paper builds on these two perspectives and moves beyond what has been a relatively narrow focus on the relationship of fishing with maritime disputes. This research draws on insights from political ecology and food regimes to trace how flows of seafood contribute to Philippines-China relations. It is argued that this 'seafood regime' between China and the Philippines constitutes a broader politicised environment (Bryant, 1998) marked by environmental unsustainability and considerably unequal exchange relations between the Philippines and China.

Fisheries resources have long been flagged as potential and actual drivers of maritime disputes (Charles, 1992; Kurlansky, 2011; Pomeroy et al., 2007; Pomeroy, Parks, Markovich \& LaMonica, 2016). For example, the analysis by Pomeroy et al. (2007) of 'fish wars' in Southeast Asia depicts a dystopian vision of conflict over fishery resources within and between states. Driven by fishery over-capacity, rapid population growth and few viable livelihoods, such conflicts result in lower incomes and food security, driving further competition and conflict (Pomeroy et al., 2007). Recently, scientists have forecast that migration patterns of fish stocks driven by climate change will contribute to increased future conflict (Pinsky et al., 2018). Although the literature on fisheries conflicts is diverse, with multiple conceptualisations and empirical foci that go beyond interstate maritime disputes (Spijkers et al., 2018), the tendency is to focus on the material dimensions of such disputes (Penney, Wilson \& Rodwell, 2017). This tendency aligns with that of peace and conflict studies, which considers environmental scarcity a trigger for conflicts and has been critiqued as reductionist (e.g. Le Billon \& Duffy, 2018; Selby, 2018).

Beyond fisheries resources, the practice of fishing can serve as the 'human frontline' (Patience, 2013; Roszko, 2017) in disputes; as a means for states to intervene more subtly in disputes. Fishing vessels are not as confrontational as military ships; however, their presence serves to legitimise state claims. Song (2015) demonstrated how state support for South 
Korean fishing vessels in waters disputed with North Korea can be a form of 'governmentality'. Through the construction of a 'maritime militia', Chinese state support for fishing in the South China Sea (SCS) is well documented (Erickson \& Kennedy, 2015). Such state support goes beyond subsidies and considers fishing a means to advance claims in disputed waters. Although the authors do not use this language, the focus of this research aligns with arguments made by Rasmussen and Lund (2018) about the ways in which territoriality produces authority. Unlike conventional perspectives that assume territorial practices come after authority is established, Rasmussen and Lund (2018) argued that territoriality is a way in which authority is actually produced. Therefore, as a form of territoriality, fishing serves to produce state authority. This emphasis on the ways in which fishing serves state goals in maritime disputes is useful to move beyond the reductionist emphasis in other literature on fisheries conflicts. However, the focus remains on how fishing and fisheries resources relate to disputed waters. In relation to the 'maritime militia', Zhang (2016, see also Zhang \& Bateman, 2017) highlighted that such a focus is overly securitised and ignores the range of drivers behind Chinese fishing activities in the SCS. This article builds on this critique and argues that such a perspective, although necessary, is incomplete and neglects how fishing contributes to the broader interstate relationship, including, but not limited to, maritime disputes.

In addition to the SCS dispute, there are several important features of fishing and fisheries resources in China and the Philippines that make them relevant to this study. China is the largest consumer of food fish in the world. Fish is used as fish feed for aquaculture, for processing and re-export, and for domestic consumption, increasingly of imported species (Cao et al., 2015 Chiu et al., 2013; Fabinyi, Barclay \& Eriksson, 2017; Villasante et al. 2013). It is the third-largest importer of fish and fish products and the largest exporter of fish and fish products $(\mathrm{FAO}, 2018)$. Although much of these exports are derived from its massive 
aquaculture sector, the distant water fishery is also a major contributor (Mallory, 2013; Pauly et al., 2014). Promotion of overseas aquaculture investments is an important component of the current administration's signature Belt and Road Initiative (Godfrey, 2018). By contrast, Philippine fisheries are far smaller in scale but are important relative to the overall national economy and for food and nutritional security, providing jobs to at least 1.5 million people and worth at least USD2.5 billion, annually (Asian Development Bank, 2014). In terms of environmental significance, the Philippines has been assessed as the 'center of the center' of marine biodiversity (Carpenter \& Springer, 2005). Trade — both imports and exports — is also a key feature of the Philippines seafood sector.

This paper takes a broader view on how fishing contributes to interstate relationships by examining how, together, state and market influences seafood flows between the Philippines and China - the seafood regime. The focus is on how this seafood regime constitutes power arrangements with specific social and environmental characteristics. This focus moves beyond declarations of who has control over contested waters and islands, to consider broader relations of power (Hornborg, 2001; Svarstad, Benjaminsen \& Overå, 2018). The ways in which fishing and fisheries resources contribute to the relationship between China and the Philippines is about more than a cause of the maritime dispute or a means to intensify the maritime dispute.

This paper will first elaborate on literature from political ecology and food regimes that structure the analysis. After a brief discussion of methods and sources, the ways in which fishing and fisheries resources has featured in the SCS dispute will be discussed. The analysis will then zoom out to examine other ways in which fishing and fisheries resources contribute to Philippines-China relations, examining patterns of trade, poaching and Chinese investments in aquaculture. Together, they constitute a seafood regime that is marked by environmental unsustainability and unequal exchange relations. 


\section{Political ecology and seafood regimes}

The approach of this paper draws from a political ecology approach to environmental conflict; instead of understanding environmental conflict as a specific, spectacular or abnormal event (such as the seizure of Scarborough Shoal), environmental conflict is considered an ongoing process in a 'politicised environment'. This paper focuses on how this process unfolds at multiple political and economic scales (Bryant, 1998; Le Billon \& Duffy, 2018; Perreault, 2015). The contrast between individual 'disputes' or 'conflicts' and a 'politicised environment' is analogous to the contrast between property (i.e., ownership or sovereignty in disputed waters) and 'access'. Ribot and Peluso (2003) explained that property is one of many access mechanisms. Other ways in which individuals or groups gain and maintain control over 'the ability to benefit from things' include technology, capital, markets, labour, knowledge, authority, identities and social relations (Ribot \& Peluso, 2003). Although this paper does not use these access mechanisms as a framework, the concept of access is useful to highlight the range of diverse and subtle ways in which contestation over resources can occur. For example, trade can be considered not a purely voluntary exchange, but embedded in social relations of power (Gereffi, Humphrey, \& Sturgeon, 2005; Hornborg, 2001). From this perspective, maritime disputes are part of a broader politicised environment in which 'conflict' is an ongoing process and natural feature of interstate relations (Bryant, 1998; Le Billon \& Duffy, 2018).

This paper draws on literature about food regimes. Food regime studies are a critical tradition drawing on world-systems theory, studying national food economies in the context of global capitalism (Bernstein, 2016; Friedmann \& McMichael, 1989; McMichael, 2009). The dominant approach to food regimes envisioned two terrestrial food regimes. The first (1870s-1930s) was centred around Britain and 'combined colonial tropical imports to Europe with basic grains and livestock imports from settler colonies' (McMichael, 2009, p. 141). The 
second (1950s-1970s) was centred around the USA and 're-routed flows of (surplus) food from the United States to its informal empire of postcolonial states on strategic perimeters of the Cold War' (McMichael, 2009, p. 141). Analysts have debated the nature of the contemporary food regime emerging since the 1970s, suggesting it may constitute a 'corporate food regime' (McMichael, 2013) or a corporate-environmental food regime (Friedmann, 2005). Although the concept of food regimes has been critiqued for its lack of nuance in periodisations (Goodman \& Watts, 1994) and for a more recent 'peasant turn' that romanticises and simplifies the livelihoods of small-scale food producers (Bernstein, 2016), the notion of food regimes is flexible and used in a variety of ways; not only as a delineation of historical periods but also as an analytical methodology or 'lens' (McMichael, 2009). The term is used here to refer to "the ways in which forms of capital accumulation in agriculture constitute global power arrangements, as expressed through patterns of circulation of food' (McMichael, 2009, p. 140). Although this paper acknowledges that the notion of food regimes tends to be used at a global scale (and to terrestrial resources), here it specifically refers to how seafood flows between China and the Philippines express power arrangements.

In one of the few applications of the concept of food regimes to seafood, Campling and Havice (2018) develop a historical typology of seafood regimes ${ }^{1}$, demonstrating how they differ from the dominant typology of terrestrial food regimes. They suggest that from around the turn of the nineteenth century until the 1960s, 'national seafood production systems' dominated, as states such as Japan and the US sought to expand and seek out new commodity frontiers. From the 1970s to the 1990s, seafood production and trade became global and management became a larger part of the discourse as awareness of the widespread effect on fish stocks grew. They suggest that from the early 2000s, a third type of seafood

\footnotetext{
${ }^{1}$ For other periodisations of seafood production in Southeast Asia and the Indo-Pacific, see Butcher (2004) and Christensen (2014).
} 
regime has emerged, centred around public-private governance partnerships such as certification (e.g., the Marine Stewardship Council). Although their analysis highlights developments in the global seafood system from the early twentieth century, they emphasise significant continuities. These include 'the volume of extraction' as the underlying logic of seafood systems and the central role of the state across seafood regimes; 'the corporateenvironmental food regime does not present a moment of privatized governance in seafood systems. It is firmly embedded in, and dependent upon, the historical institutions of national seafood production systems' (Campling \& Havice, 2018, p. 88).

The strong presence of the state relates to the analysis of Chinese food systems, because of the particularly strong role of the state in China. Belesky and Lawrence (2018) suggest that China's expanded role in the global food regime over the past several decades highlights the increased importance of state-led capitalism and neo-mercantilism. They argue that the re-emergence of China in the global food regime is a feature of 'an increasingly multi-polar food regime' (p. 11) that is characterised by different types of capitalism. They focus on the scale and significance of large state-owned enterprises 'going global' and making foreign acquisitions. Although the Chinese seafood sector is also committed to foreign acquisitions and investment, its central role across global seafood production, consumption and trade make it more broadly significant (Cao et al., 2015; Villasante et al., 2013; Zhan, Zhang \& He, 2018; Zhang, 2018b). Therefore, this paper avoids the heavily 'securitised' depiction of fisheries and seafood in the SCS critiqued by Zhang (2016), but remains focused on how seafood flows constitute power relations between states.

\section{Methods}

This paper draws on several sources. Primarily, it draws on public material from media and government sources, including newspapers and the UN Comtrade Database (UN Comtrade 
Database, 2018). While some of this material has been published already (e.g. media reports), the ways in which they are linked together to support my original argument about the linkages between fisheries and interstate relationships has not. Secondly, the paper draws on interviews and focus groups with Philippines-based stakeholders in the SCS dispute, which helped to validate many of the claims made by journalists. Between May and July of 2017, two focus groups and 10 one-on-one semi-structured interviews were conducted with fishers located in Subic and Masinloc, Zambales province; locations where many fishers travel to the disputed Scarborough Shoal for fishing. The focus groups and interviews discussed the history of fishing in the region, the effects of the dispute on livelihoods, the status of the dispute and current fishing activities. In July 2018, six semi-structured interviews were conducted with key informants in Manila, including members of the government and academics. These interviews focused on the status of Philippine-China relations and the role of fisheries. Thirdly, the paper also draws on my long-term ethnographic experience with fishers from different areas of the Philippines who fish in the SCS (e.g., Author ${ }^{2}, 2012 \mathrm{a}$; Author, 2012b) and previously published work on Chinese seafood consumption and trade (e.g., Author, 2014).

\section{Fisheries resources, fishing and the South China Sea dispute}

The People's Republic of China has overlapping claims over the SCS with Brunei, Indonesia, Malaysia, the Philippines, Taiwan and Vietnam. Although the dispute between the Philippines and China has existed for many decades, it intensified in the late 2000s and dramatically in 2012 with the occupation of Scarborough Shoal by China. Filipino fishers were prevented from fishing in the area, harassed by Chinese coastguard vessels (e.g.,

\footnotetext{
2 'Author' is used here for anonymity.
} 
through use of water cannon). Then-president Aquino adopted a confrontational stance, filing a case against China with the UN in 2013 (see Heydarian, 2015; Kaplan, 2015). The dispute caused relations between China and the Philippines to sour and Philippine agricultural exports to China were affected (Reuters, 2012) ${ }^{3}$. In 2016, the Permanent Court of Arbitration ruled in favour of the Philippines. China did not participate in the arbitration and has not recognised the ruling. The formal legal status of Scarborough Shoal and the SCS remains contested and China retains de facto control of Scarborough Shoal. China and the Philippines seek increased control in other parts of the SCS such as in the Spratly Islands. President Duterte has not pressed the issue and has adopted a more conciliatory approach with China. Shortly following his election, Filipino fishers were then allowed to fish around the Shoal, although still not inside it. During a 2016 visit to Beijing, USD24 billion worth of Chinese investment in the Philippines was announced. Now, leaders of China and the Philippines regularly meet through the bilateral consultative mechanism (Fook, 2018). Although fisheries form part of these discussions, few concrete measures on fisheries cooperation have been implemented. In the SCS, better fisheries management is required; a 2016 report estimated that fish stocks in the SCS declined to between five and 30 per cent from the 1950s (Sumaila \& Cheung, 2016). Although detailed, credible proposals have been researched and advocated for fisheries cooperation among the claimants (Asia Maritime Transparency Initiative SCS Working Group, 2017; Langenheim, 2015; Zhang, 2018a), there has been little take-up by high-level policymakers.

The dominant discourses outlined in the introduction - fisheries resources as a material factor motivating conflict, and fishing practices as a tool to generate authority - are features of the SCS dispute. The ecological and economic value of the marine resources of

\footnotetext{
${ }^{3}$ In other cases, China has used informal sanctions on fish against countries with which it has political disputes (e.g., salmon in the case of Norway [Chen \& Garcia, 2016]).
} 
the SCS is one of the factors fuelling the dispute. Approximately 12 per cent of global fisheries derive from the SCS, and in 2012 the landed value was estimated at USD21.8 billion (Sumaila \& Cheung, 2016). The SCS is a spawning site for many fish that eventually end up in coastal areas of surrounding countries. These fisheries resources are central to the economies of developing countries on the coast of the SCS, the livelihoods of many of their coastal residents and important as a source of cheap and nutritious food. China, the Philippines and other states in the region have overfished their domestic waters (Anticamara \& Go, 2016; Zhang, 2016), making the SCS an increasingly attractive marine resource frontier. This is reflected in Filipino fishers' comments about what they view as a change in patterns of ownership in recent years-from a common resource 'nobody owned' to one in which state enclosures increasingly restrict fishing access (Fabinyi, 2016a; Schober, 2018). These facts have led analysts to conclude that the dispute is driven by competition over lucrative, yet increasingly scarce, fishery resources (e.g., Greer, 2016; Schofield, Sumaila \& Cheung, 2016). This conclusion is in line with much literature on fisheries conflict (Penney et al., 2017).

The ways states have used the fishing industry to further claims in the SCS has been well documented. The Chinese government has provided significant subsidies, provisions of technical resources (e.g., satellite communications equipment) and basic military training to fishers from Hainan province, creating a 'maritime militia' (Erickson, 2016; Erickson \& Kennedy, 2015). After the Chinese military occupied Scarborough Shoal from 2012, Chinese fishing vessels began fishing for giant clam shells, which were traded to Hainan. President Xi Jinping visited the epicentre of giant clam trading - the fishing town of Tanmen in Hainanin April 2013, encouraging fishers to fish in the SCS. Although the trade in giant clams was banned in 2017, the fishing that was encouraged was environmentally destructive. The method uses boat propellers to dig up the clams, destroying the reefs. One assessment 
discovered that, although island building has destroyed 55 square kilometres of coral reefs around the SCS, the methods for catching giant clams has destroyed almost double that amount; 104 square kilometres of coral reefs (McManus, cited in Cyranoski, 2016). Although the extent to which geopolitical concerns motivate Chinese fishing activities in the SCS is debated (Zhang, 2016), it is clear that the Chinese government strategically considers the expansion of fishery activities in the SCS.

The Philippine government also considers fishing activities a means to promote their claims in disputed waters. Part of the Spratly Islands in the SCS, the municipality of Kalayaan in Palawan province has a population of only 184 people. However, the government has aimed to promote the fishing industry there. In 2017, they relocated 50 fishers and some of their family members from another part of Palawan province and announced plans for a fishing festival (Palawan News, 2017). At a larger scale, the emerging discourse of the 'blue economy' is seen by some national-level policy stakeholders as a means to combine increased and more efficient fisheries development with national security (Interview, July 2018). However, in the Philippines, fishing is more often used by governments to evoke sympathy for the Philippines' people. As part of his strategy to appeal to the international community, President Aquino frequently referred to the plight of Filipino fishermen prevented from accessing Scarborough Shoal (South China Morning Post, 2014). Poor fishers from Subic and Zambales provinces, for example, worked as small-scale fishers during the fishing season (approximately January-April) in Scarborough Shoal. From 20132016, these fishers had to find alternative sources of income such as fishing elsewhere, tricycle driving or farming. President Duterte secured access rights for these fishers as one of his first objectives after becoming president in 2016 when he visited China (Ranada, 2016). His strategy is informed by recognition of the unequal power relations between the two countries - acknowledging the reality that the Philippines would be obliterated by China in a 
conventional war. His strategy has been to be 'meek and humble' (Rappler, 2018). Fishing and fisheries resources are therefore important as symbolic devices for the Philippine government to promote its interests in maritime disputes; however, differently to the overtly aggressive 'maritime militia' of China.

Another example of how marine resources serve as an important feature of maritime disputes between the Philippines and China is off the eastern coast of the Philippines in Benham Rise. Since 2014, tensions have risen over Chinese exploration rights, potential cooperative scientific research between the two countries and naming of underwater features (ABS-CBN, 2018). A more recent issue has been the construction of Chinese weather stations in the Spratly Islands (Andrade, 2018). As Batongbacal notes, 'China's installation of "weather stations" should be viewed as part of the continued development and enhancement of military bases in China's artificial islands, and as an extension of their efforts to gain de facto control of the SCS' (Batongbacal, 2018).

\section{Seafood regimes}

Just as the relationship between China and the Philippines is not defined by the narrow focus on the dispute (Ang-See \& Romana, 2013), the ways in which fishing contributes to this relationship is broader than its contribution to the dispute. Fishing and the procurement of seafood by China and the Philippines has a diverse range of drivers and outcomes, many of which are not related to security or the dispute (Zhang \& Bateman, 2017). The remainder of this essay will demonstrate how flows of fish between the Philippines and China represent a broader 'seafood regime', focusing on trade, poaching and aquaculture investments.

Trade is the primary way in which the contours of the Philippine-China seafood regime is most evident. Seafood trade flows are highly unequal, with China exporting more to the Philippines than the Philippines has been exporting to China since around 2010 (see 
Figure 1). It is not clear why there has been such a dramatic change since this period, although it may be linked to the expanded activities of the Chinese distant water fishery (see Figure 1).

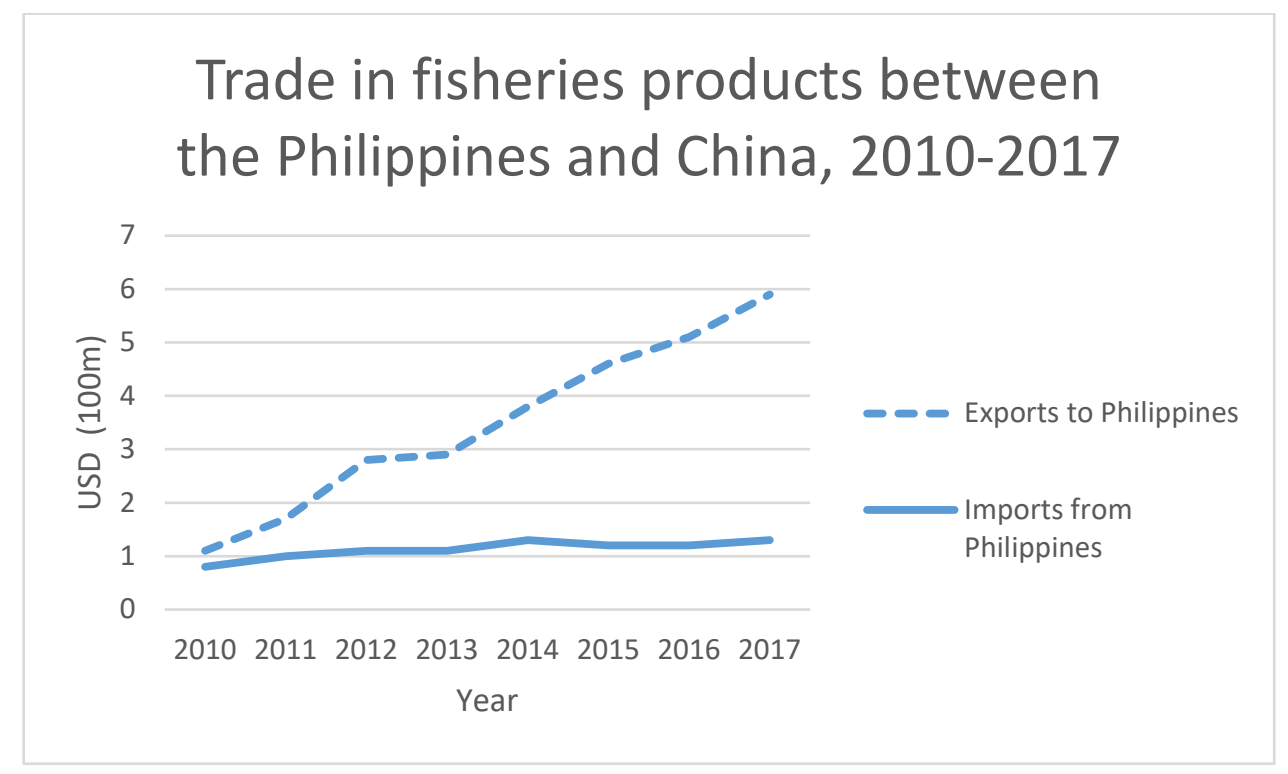

Figure 1. Trade in fishery products between the Philippines and China, 2010 to 2017. Because of the status of Hong Kong as a re-export hub for high-value seafood to mainland China, which is not well documented in official statistics (Eriksson \& Clarke, 2015; Fabinyi et al., 2017; Sadovy de Mitcheson et al. 2017), 'China' refers to mainland China and Hong Kong, SAR. Source: UN Comtrade Database (commodity code 03).

Much of the fish exported from China to the Philippines is frozen. In 2017, of the USD589 million worth of fishery products exported to the Philippines, over half was frozen fish (USD303 million, commodity code 0303 ), of which approximately half (24 per cent of total exports) were small mackerels, (USD139 million, commodity code 030354). Approximately 30 per cent (USD177 million) were molluscs (commodity code 0307 ), of which virtually all were 'cuttlefish and squid' (USD164 million, commodity code 030743). Both of these types of fish (small mackerels and squid) are likely to have been caught by the significant Chinese distant water fishery (Hornby, 2017; Mallory, 2013). For many years, the Chinese distant water fishery has been considered by China a key means of obtaining profits, employment and (to a lesser degree) contributing to national food security (Mallory, 2013). 
This fishery is not well documented and Pauly et al. (2014) assert that catches are substantially under-reported. In common with distant water fisheries of other nations, environmental sustainability is not a major concern (Mallory, 2013). Although recent Chinese government policies have capped the number of distant water fishing vessels to 3000 by 2020 (Mallory, 2017), environmentally harmful subsidies remain a feature (Mallory, 2016).

Imports of small fish into the Philippines, including from China, are controversial. In 2018, fisherfolk non-government organisation (NGO) Pamalakaya organised protests against the importation of round scads, including from China. They argued that this importation would economically disadvantage local fishers, raise fish prices and claimed that the imported fish was low quality and treated with the toxic chemical formalin (De Vera-Ruiz, 2018). Although it is difficult to disentangle the positive and negative effects of fish imports for seafood producers and consumers in the Philippines, the power relations are clear. Chinese subsidies to its distant water fishery have attracted broader charges of 'dumping' by a range of international actors and have been disputed at the World Trade Organisation (South China Morning Post, 2017).

In contrast, much of the Philippines' exports to China are for high-value seafood. In 2017, of the USD132 million worth of fishery products exported to China and Hong Kong, 80 per cent was comprised of live fish (USD4 million, commodity code 0301 ) and crustaceans (USD1 million, commodity code 0306). Live fish are likely to be primarily composed of live reef food fish (Sadovy de Mitcheson et al., 2017). The live reef fish trade in the Philippines is an important fishery, with significant environmental and social effects. Most live fishing targets groupers and other reef fish, which are mostly caught by poor smallscale fishers (Fabinyi, 2016b). Overfishing has been well documented, with the live fish trade in the Philippines and elsewhere driven by a range of fishing practices including targeting sub-adult fish (as plate-sized fish are preferred by Chinese consumers), targeting of spawning 
aggregations and the use of cyanide (which also destroys corals) (Sadovy et al., 2003).

Groupers are relatively long-lived and slow to reproduce, and vulnerable to overfishing. The humphead wrasse (Cheilinus undulatus) is listed as 'endangered', while other species in the trade are 'vulnerable' (humpback grouper, Cromileptes altiveles) or 'near-threatened' (coral trout, Plectropomus leopardus) on the IUCN Red List. The trade is regarded by many governments as unsustainable and has long been a target for environmental NGOs (Sadovy de Mitcheson et al., 2017). The vast differences in terms of volumes and types of fisheries targeted for trade highlights the unequal power relations between the two countries.

The trade has also had social effects; many fishers who use hookah equipment to dive for fish suffer from decompression sickness (Pauwelussen, 2017). Across the trade there are concerns about the economic distribution of benefits. Many fishers are financed by traders, who are financed by exporters, who are financed by Hong Kong-based or mainland Chinesebased traders (Fabinyi, 2016b). Fishers who are financed receive lower prices than those who are independent. A value chain analysis conducted by Trinidad et al. (2014) concluded that traders based in Hong Kong and China captured a greater proportion of the value than actors in the Philippines. Although this trade is lucrative and has brought significant short-term economic benefits, due to the terms of trade fishers do not receive as many benefits as they could. In China, most live reef fish from the Philippines end up as luxury banquet items costing several hundreds of dollars per kilogram (Fabinyi, 2016b). There is a stark contrast between the lives of collectors and those consuming the fish at each end of the commodity chain.

In addition to trade, blatant poaching is another means of obtaining fisheries resources. At the most direct level, poaching in Philippine waters by Chinese fishing vessels is common. Between 1995 and 2014, in the province of Palawan, approximately 100 vessels were held, of which just under half were Chinese. More than 1000 people were detained, of 
whom more than half were Chinese (Boehler, 2014). The effects on endangered species are significant. In 2006, a high-profile case involving the Chinese vessel Hoi Wan involved more than 300 live endangered humphead wrasse (Lee-Brago, 2006). Other commonly poached products are turtles, corals and shark fins. The trade in all of these species is prohibited in the Philippines. Common poaching zones include important turtle breeding grounds and some of the richest coral reefs in the world. Much of this poaching occurs in waters that do not lie in the disputed zones of the SCS, but are within the Philippines such as the renowned diving destination Tubbataha Reef National Marine Park in the Sulu Sea (Lee-Brago, 2006). Although poaching activities also regularly involve Filipino fishers, the failure of local authorities to regulate them means that many high-value, endangered and illegally caught fish are smuggled from the Philippines to China. The point is not to blame a country; for example, the Chinese government may not be directly involved in these activities. Rather, the prevalence of poaching highlights how easily market demand can overwhelm weak institutions (Berkes et al., 2006; Scales, Balmford, Liu, Sadovy \& Manica, 2006).

A different form of theft involves confiscation of high-value fish from Filipino fishers at Scarborough Shoal. Fishers advised in interviews that when they are fishing in small (e.g., three-metre long) pump boats, larger Chinese coastguard vessels would approach and ask for fish. One fisher described how because of the difference in size and power, fishers would feel pressured to comply and see it as a form of 'bullying' (Interview, May 2017). Now he says he hides most of his catch when they come near, so that he doesn't have to give the fish to them. Another one noted that Chinese Coastguard vessels also sometimes come very near just to observe them, which according to fishers serves as a form of intimidation (Interview, May 2017). Such activities were publicised in the Philippines earlier in 2018. Although President Duterte has insisted that they were cases of 'barter' and that any problems came down to misunderstandings over 'valuation' (Placido, 2018b), evidence from fishers in interviews 
with myself and media organisations (e.g. Placido, 2018a) demonstrate that this explanation lacks credibility. China now has de facto control over fishing activities in and around Scarborough Shoal and has the power to choose what fish to extract from Filipino fishers.

The expansion of aquaculture is another component of the seafood regime between China and the Philippines. China is the global leader in aquaculture production (FAO, 2018). Part of the Belt and Road Initiative includes aquaculture investments in other countries (Godfrey, 2018). It would appear that aquaculture could serve as a significant means of fisheries cooperation between China and the Philippines. In 2017, during a visit to the Philippines, aquaculture was explicitly highlighted by then-Vice Premier Wang Yang as a focus of Chinese investment (Philippine Daily Inquirer, 2017). In late 2017, 50,000 fingerlings of coral trout were shipped to Palawan and Davao each and there were plans for a Chinese delegation to investigate investments in mariculture parks in Palawan (Interaksyon, 2017). However, actual investment in aquaculture has been limited. This reflects the broader pattern of Chinese investment in the Philippines; although much was made of USD24 billion worth of Chinese pledges after President Duterte's trip to China in 2016, by late 2018, little of these funds have been approved for specific projects or spent. Authors such as Clemente (2016) and Camba (2018) highlighted that Chinese economic engagement in the Philippines is weak compared to Southeast Asian neighbours. In some cases, this is due to different expectations and goals on the side of the Philippines. For example, the head of a Philippine commercial fishing association who was part of a delegation that visited China noted that the Chinese were keen to invest in aquaculture in parts of Zambales province (see also Zhang, 2018). However, the local Zambales stakeholders were more interested in investments in improved capacity and technology for capture fisheries (Focus group discussion, July 2017). Many fishing households and businesses were heavily invested in the capture fisheries industry, and did not see aquaculture as a viable economic opportunity. Additionally, 
aquaculture was perceived to generate significant environmental impacts through pollution (Focus group discussion, July 2017). As such, aquaculture investment has not proceeded there. Although aquaculture investments have not widely proceeded, the fact that the only substantial project so far is for coral trout to be traded to China-as opposed to species widely consumed and farmed in the Philippines such as milkfish (Chanos chanos) or rabbitfish (Siganidae) — may be an early indication of the sorts of projects that are likely to succeed.

\section{Conclusion}

Given Chinese involvement in maritime disputes (Fravel, 2014) and its expanding role in the global production, distribution and consumption of seafood, understanding how Chinese seafood and fisheries relates to broader geopolitical relationships is particularly significant (Zhang, 2018). In the case of China and the Philippines, three features of the ChinaPhilippines seafood regime are apparent. First, environmental damage is a recurring theme; in the state-sponsored clam fishing activities and island-building in disputed areas, in the statesponsored distant water fishery that supplies most of the fish traded to the Philippines and in the live reef fish trade that forms the main component of trade flows in the other direction from Philippines to China. Although environmental unsustainability is not unique to either country, the emerging public-private governance regimes of certification discussed by Campling and Havice (2018) characterising the third seafood regime do not feature strongly, if at all. Second, although seafood trade relations are complex, with a mixture of positive and negative effects (Béné et al., 2016; Béné, Lawton \& Allison, 2010), in this context, relations are highly unequal. China exports large amounts of low-value fish to the Philippines while ensuring that any environmental costs are in distant waters, attracting charges of dumping. In contrast, the Philippines exports high-value fish while retaining fewer financial benefits and 
accruing significant environmental costs. Third, although it is likely in the future that aquaculture will generate an increased volume of seafood to China, to date, Chinese investments in the Philippines have not yet been realised.

A range of economic and political factors mean that maritime disputes may become more prominent in the coming years (Fravel, 2014). Fishing and fisheries resources will continue to form an important component of these disputes, as a driver of disputes and a means by which actors advance their claims. However, a narrow focus on the contribution of fishing and fisheries resources to maritime disputes obscures the diverse ways in which they generally relate to interstate relationships. By contrast, a focus on seafood regimes between countries, composed of trade, poaching and investments, demonstrates how power is exercised not only through spectacular events (e.g., seizure of a reef, prohibitions against foreign fishers and using water cannons against fishers) but also through the more mundane, everyday unequal relationships between two countries. This is the basis of a 'politicised environment' (Bryant, 1998), in which diverse forms of exchange and accumulation generate, maintain and reinforce inequalities (Hornborg, 2001). From this perspective, seafood flows, as with food flows more generally (McMichael, 2009), are an important site for the expression of economic and political power. As global attention increasingly turns to exploitation of the oceans as one of the planet's last frontier spaces (Steinberg, 2018), understanding the power dynamics inherent in this process will become more relevant.

\section{References}

ABS-CBN. (2018, 15 February). Protest vs Chinese names for PH rise features may be too late - expert. $A B S-C B N$ News. Retrieved from https://news.abscbn.com/news/02/15/18/protest-vs-chinese-names-for-ph-rise-features-may-be-toolate-expert

Andrade, J. (2018, 6 November). 'Protest Chinese weather stations on PH reefs' - maritime law expert. Philippine Daily Inquirer. Retrieved from 
https://globalnation.inquirer.net/170816/protest-chinese-weather-stations-on-ph-reefsmaritime-law-expert

Ang-See, T. \& Romana, C. S (eds). (2013). Philippines-China relations: Sailing beyond disputed waters. China Studies Journal, 10.

Asia Maritime Transparency Initiative South China Sea Working Group. (2017). A blueprint for fisheries management and environmental cooperation in the South China Sea. Retrieved from https://amti.csis.org/coc-blueprint-fisheries-environment/

Asian Development Bank. (2014). Economics of fisheries and aquaculture in the coral triangle. Retrieved from https://www.adb.org/sites/default/files/publication/42411/economics-fisheriesaquaculture-coral-triangle.pdf

Anticamara, J. A. \& Go, K. T. (2016). Spatio-temporal declines in Philippine fisheries and its implications to coastal municipal fishers' catch and income. Frontiers in Marine Science, 3, 21.

Batongbacal, J. (2018, 5 November) Twitter. Retrieved from https://twitter.com/JayBatongbacal/status/1059627896359182336

Belesky, P. \& Lawrence, G. (2018). Chinese state capitalism and neomercantilism in the contemporary food regime: Contradictions, continuity and change. The Journal of Peasant Studies, 1-23.

Béné, C., Arthur, R., Norbury, H., Allison, E.H., Beveridge, M., Bush, S., ... Williams, M. (2016). Contribution of fisheries and aquaculture to food security and poverty reduction: Assessing the current evidence. World Development 79, 177-196.

Béné, C., Lawton, R. \& Allison, E. H. (2010). 'Trade matters in the fight against poverty': Narratives, perceptions and (lack of) evidence in the case of fish trade in Africa. World Development, 38(7), 933-954.

Berkes, F., Hughes, T. P., Steneck, R. S., Wilson, J. A., Bellwood, D. R., Crona, B., ... Nyström, M. (2006). Globalization, roving bandits and marine resources. Science, $311(5767), 1557-1558$.

Bernstein, H. (2016). Agrarian political economy and modern world capitalism: The contributions of food regime analysis. The Journal of Peasant Studies, 43(3), 611647.

Boehler, P. (2014, 17 June). Chinese fishermen held in Philippines defiant ahead of turtlepoaching trial. China Insider. Retrieved from 
https://www.scmp.com/news/asia/article/1533938/chinese-fishermen-held-

philippines-defiant-ahead-turtle-poaching-trial

Bryant, R. L. (1998). Power, knowledge and political ecology in the third world: A review. Progress in Human Geography, 22(1), 79-94.

Butcher, J., (2004). The closing of the frontier. Singapore: Institute of Southeast Asian Studies.

Camba, A. (2018). The Philippines' Chinese FDI boom: More politics than geopolitics. New Mandala. Retrieved from http://www.newmandala.org/duterte-philippines-chineseinvestment-boom-politicsgeopolitics/?utm_content=bufferf8799\&utm_medium=social\&utm_source=twitter.co $\underline{\text { m\&utm campaign }=\text { buffer }}$

Campling, L. \& Havice, E. (2018). The global environmental politics and political economy of seafood systems. Global Environmental Politics, 18(2), 72-92.

Cao, L., Naylor, R., Henriksson, P., Leadbitter, D., Metian, M., Troell, M. \& Zhang, W. (2015). China's aquaculture and the world's wild fisheries. Science, 347(6218), 133135.

Carpenter, K. E. \& Springer, V. G. (2005). The center of the center of marine shore fish biodiversity: The Philippine Islands. Environmental biology of fishes, 72(4), 467-480.

Charles, A. T. (1992). Fishery conflicts: A unified framework. Marine Policy, 16(5), 379393.

Chen, X. \& Garcia, R. J. (2016). Economic sanctions and trade diplomacy: Sanction-busting strategies, market distortion and efficacy of China's restrictions on Norwegian salmon imports. China Information, 30(1), 29-57.

Chiu, A., Li, L., Guo, S., Bai, J., Fedor, C. \& Naylor, R. L. (2013). Feed and fishmeal use in the production of carp and tilapia in China. Aquaculture, 414, 127-134.

Christensen, J. (2014). Unsettled seas: Towards a history of marine animal populations in the central Indo-Pacific. In J. Christensen \& M. Tull (Eds.), Historical perspectives of fisheries exploitation in the Indo-Pacific (pp. 13-39). New York: MARE Publication Series 12. Springer, Dordrecht.

Clemente, T. S. (2016). Understanding the economic diplomacy between the Philippines and China. International Journal of China Studies, 7(2), 215.

Cyranoski, D. (2016). Ecosystem fear in South China Sea. Nature, 535, 334. 
De Vera-Ruiz. (2018, 5 September). Pamalakaya urges BFAR to conduct laboratory testing on 1st batch of 'imported 'GG'. Philippine Star. Retrieved from https://news.mb.com.ph/2018/09/05/pamalakaya-urges-bfar-to-conduct-laboratorytesting-on-1st-batch-of-imported-gg/

Erickson, A. S. (2016). China's blueprint for sea power. China Brief, 16(11), 2-6.

Erickson, A. S. \& Kennedy, C. M. (2015, 31 March). Meet the Chinese maritime militia waging a 'people's war at sea'. Wall Street Journal. Retrieved from https://blogs.wsj.com/chinarealtime/2015/03/31/meet-the-chinese-maritime-militiawaging-a-peoples-war-at-sea/

Eriksson, H. \& Clarke, S. (2015). Chinese market responses to overexploitation of sharks and sea cucumbers. Biological Conservation, 184, 163-173.

FAO. (2018). The State of World Fisheries and Aquaculture 2018 - Meeting the sustainable development goals. Retrieved from http://www.fao.org/documents/card/en/c/19540EN/

Fabinyi, M. (2016a, 7 June). New dynamic for South China Sea Fisheries. Australian Outlook. Retrieved from http://www.internationalaffairs.org.au/australian_outlook/new-dynamicfor-southchina-sea-fisheries/

Fabinyi, M. (2016b). Producing for Chinese luxury seafood value chains: Different outcomes for producers in the Philippines and North America. Marine Policy, 63, 184-190.

Fabinyi, M., Barclay, K. \& Eriksson, H. (2017). Chinese trader perceptions on sourcing and consumption of endangered seafood. Frontiers in Marine Science, 4, 181.

Fook, L. L. (2018). The China-Philippine bilateral consultative mechanism on the South China Sea: Prospects and challenges. Perspective. Retrieved from https://www.iseas.edu.sg/images/pdf/ISEAS Perspective 2018 14@,50.pdf

Fravel, M. T. (2014) Territorial and maritime boundary disputes in Asia. In S. M. Pekkanen, J. Ravenhill \& R. Foot (Eds.), Oxford handbook of the International Relations in Asia. New York, NY: Oxford University Press.

Friedmann, H. (2005). From colonialism to green capitalism: Social movements and emergence of food regimes. In F. H Buttel \& P. McMichael (Eds.), New directions in the sociology of global development (pp. 227-264). Amsterdam: Elsevier. 
Friedmann, H. \& McMichael, P. (1989). Agriculture and the state system: The rise and decline of national agricultures, 1870 to the present. Sociologia ruralis, 29(2), 93117.

Gereffi, G., Humphrey, J., \& Sturgeon, T. (2005). The governance of global value chains. Review of international political economy, 12(1), 78-104.

Godfrey, M. (2018, 19 June). From Indonesia to Norway, China looking to invest in aquaculture overseas. Seafood Source. Retrieved from https://www.seafoodsource.com/features/china-wants-to-invest-in-tropicalaquaculture-overseas

Goodman, D. \& Watts, M. (1994). Reconfiguring the rural or fording the divide? Capitalist restructuring and the global agro-food system. The Journal of Peasant Studies, 22(1), $1-49$.

Greer, A. (2016, 20 July). The South China Sea is really a fishery dispute. The Diplomat. Retrieved from https://thediplomat.com/2016/07/the-south-china-sea-is-really-afishery-dispute/

Heydarian, R. J. (2015). Asia's new battlefield: The USA, China and the struggle for the Western Pacific. London: Zed Books Ltd.

Hornborg, A. (2001). The power of the machine: Global inequalities of economy, technology and environment (Vol. 1). Maryland, United States: Rowman Altamira.

Hornby, L. (2017, 28 March). A bigger catch: China's fishing fleet hunts new ocean targets. Financial Times. Retrieved from https://www.ft.com/content/e7bd4094-ff34-11e6$\underline{96 \mathrm{f} 8-3700 \mathrm{c} 5664 \mathrm{~d} 30}$

Interaksyon (2017, 21 November). Chinese investors set eyes on aquaculture prospects in Palawan. Interaksyon. Retrieved from http://www.interaksyon.com/breakingnews/2017/11/21/109800/chinese-investors-set-eyes-on-aquaculture-prospects-inpalawan/

Kaplan, R. D. (2015). Asia's cauldron: The South China Sea and the end of a stable Pacific. New York: Random House Trade Paperbacks.

Kurlansky, M. (2011). Cod: A biography of the fish that changed the world. Toronto: Vintage Canada.

Langenheim, J. (2015) Preventing ecocide in the South China Sea. The Guardian. Retrieved from https://www.theguardian.com/environment/the-coraltriangle/2015/jul/15/preventing-ecocide-in-south-china-sea 
Le Billon, P. \& Duffy, R. V. (2018). Conflict ecologies: Connecting political ecology and peace and conflict studies. Journal of Political Ecology, 25(1), 239-260.

Lee-Brago, P. (2006, 29 December). Chinese embassy protests arrest of poachers in Tubbataha. Philstar Global. Retrieved from

https://www.philstar.com/headlines/2006/12/29/377274/chinese-embassy-protestsarrest-poachers-tubbataha

Mallory, T. G. (2013). China's distant water fishing industry: Evolving policies and implications. Marine Policy, 38, 99-108.

Mallory, T. G. (2016). Fisheries subsidies in China: Quantitative and qualitative assessment of policy coherence and effectiveness. Marine Policy, 68, 74-82.

Mallory, T. G. (2017, 19 December). Fishing for sustainability: China's new metered approach to global fishing. Policy Forum. Retrieved from https://www.policyforum.net/fishing-for-sustainability/

McMichael, P. (2009). A food regime genealogy. The Journal of Peasant Studies, 36(1), 139-169.

McMichael, P. (2013). Food regimes and agrarian questions. Halifax, NS: Fernwood.

Palawan News (2017, 25 September). Kalayaan town to hold fishing fest. Palawan News. Retrieved from https://palawan-news.com/kalayaan-town-hold-fishing-fest/

Patience, M. (2013, 15 January). Fishing on the frontline amid South China Sea dispute. $B B C$ News. Retrieved from https://www.bbc.com/news/world-asia-china-21008639

Pauly, D., Belhabib, D., Blomeyer, R., Cheung, W. W., Cisneros-Montemayor, A. M., Copeland, D., ... Österblom, H. (2014). China's distant-water fisheries in the 21st century. Fish and Fisheries, 15(3), 474-488.

Pauwelussen, A. P. (2017). Amphibious anthropology (Doctoral dissertation, Wageningen University). Retrieved from https://library.wur.nl/WebQuery/wurpubs/516929

Penney, R., Wilson, G. \& Rodwell, L. (2017). Managing sino-ghanaian fishery relations: A political ecology approach. Marine Policy, 79, 46-53.

Perreault, T., Bridge, G. \& McCarthy J. (Eds.). (2015). The Routledge handbook of political ecology. London: Routledge.

Philippine Daily Inquirer. (2017, 19 March). Wang Yang's visit to PH to further boost economic ties with China. Philippine Daily Inquirer. Retrieved from https://globalnation.inquirer.net/153543/wang-yangs-visit-ph-boost-economic-tieschina 
Pinsky, M. L., Reygondeau, G., Caddell, R., Palacios-Abrantes, J., Spijkers, J. \& Cheung, W. W. (2018). Preparing ocean governance for species on the move. Science, 360(6394), 1189-1191.

Placido, D. (2018a, 11 June). China still rules over Scarborough Shoal, say Filipino fishermen. $A B S-C B N$. Retrieved from https://news.abs-cbn.com/news/06/11/18/china$\underline{\text { still-rules-over-scarborough-shoal-say-filipino-fishermen }}$

Placido, D. (2018b, 18 June). Duterte on bullying of Filipinos in Scarborough: It was barter, not outright seizure. $A B S-C B N$. Retrieved from https://news.abscbn.com/news/06/18/18/duterte-on-bullying-of-filipinos-in-scarborough-it-wasbarter-not-outright-seizure

Pomeroy, R., Parks, J., Mrakovcich, K. L. \& LaMonica, C. (2016). Drivers and impacts of fisheries scarcity, competition and conflict on maritime security. Marine Policy, 67, 94-104.

Pomeroy, R., Parks, J., Pollnac, R., Campson, T., Genio, E., Marlessy, C., ... Hue, N. T. (2007). Fish wars: Conflict and collaboration in fisheries management in Southeast Asia. Marine Policy, 31(6), 645-656.

Ranada, P. (2016, 23 October). Duterte and Xi talked about fishing rights in Scarborough Shoal. Rappler. Retrieved from https://www.rappler.com/nation/150052-dutertebrought-up-fishing-rights-china-xi

Rappler (2018). Duterte: 'Remain meek, humble' to get 'mercy' of China's Xi. Rappler. Retrieved from https://www.rappler.com/nation/202674-duterte-china-xi-jinpingmeek-humble-west-philippine-

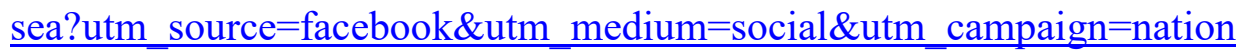

Rasmussen, M. B. \& Lund, C. (2018). Reconfiguring frontier spaces: The territorialization of resource control. World Development, 101, 388-399.

Reuters (2012). Philippines seeks new markets amid sea dispute with China. Reuters.

Retrieved from https://www.reuters.com/article/uk-philippines-chinaidUSLNE84G02520120517

Ribot, J. C. \& Peluso, N. L. (2003). A theory of access. Rural sociology, 68(2), 153-181.

Roszko, E. (2017, 1 April). South China Sea: The fishermen on the front lines. The Diplomat. Retrieved from https://thediplomat.com/2017/04/south-china-sea-the-fishermen-onthe-front-lines/ 
Sadovy, Y. J., Donaldson, T. J., Graham, T. R., McGilvray, F., Muldoon, G. J., Phillips, M. J., ... Yeeting, B. (2003). While stocks last: The live reef food fish trade. Manila: Asian Development Bank. Retrieved from https://www.adb.org/sites/default/files/publication/28455/live-reef-complete.pdf

Sadovy de Mitcheson, Y., Tam, I., Muldoon, G., le Clue, S., Botsford, E. \& Shea, S. (2017). The trade in live reeffood fish - Going, going, gone. (Volume 1: Main Report. Parts I, II \& III, pp.1-288). Hong Kong: ADM Capital Foundation and The University of Hong Kong, Hong Kong Special Administrative Region.

Scales, H., Balmford, A., Liu, M., Sadovy, Y. \& Manica, A. (2006). Keeping bandits at bay? Science, 313(5787), 612-614.

Schober, E. (2018). Between a Rock and a Stormy Place: From Overheating to Expulsion in Subic Bay (Philippines). Ethnos, 83(3), 473-488.

Schofield, C. H., Sumaila, R. \& Cheung, W. (2016, 16 August). Fishing, not oil, is at the heart of the South China Sea dispute. The Conversation. Retrieved from https://theconversation.com/fishing-not-oil-is-at-the-heart-of-the-south-china-seadispute-63580

Selby, J. (2018). Climate change and the Syrian civil war, Part II: The Jazira's agrarian crisis. Geoforum. https://doi.org/10.1016/j.geoforum.2018.06.010

South China Morning Post. (2014, 25 February). Philippines condemns Beijing's use of water cannon on fishermen in South China Sea. South China Morning Post. Retrieved from https://www.scmp.com/news/asia/article/1434925/philippines-condemns-beijings-usewater-cannon-fishermen-south-china-sea

South China Morning Post (2017, 2 November). China suggests watered-down curbs on fishery subsidies at WTO, but nations don't take bait. South China Morning Post. Retrieved from https://www.scmp.com/news/china/policiespolitics/article/2118123/china-suggests-watered-down-curbs-fishery-subsidies-wto

Spijkers, J., Morrison, T. H., Blasiak, R., Cumming, G. S., Osborne, M., Watson, J. \& Österblom, H. (2018). Marine fisheries and future ocean conflict. Fish and Fisheries, 19(5), 798-806.

Song, A. M. (2015). Pawns, pirates or peacemakers: Fishing boats in the inter-Korean maritime boundary dispute and ambivalent governmentality. Political Geography, 48, $60-71$.

Steinberg, P. E. (2018). The ocean as frontier. International Social Science Journal. 
Sumaila, U. R. \& Cheung, W. W. L. (2016). Boom or bust: The future of fish in the South China Sea. Retrieved from https://www.oceanrecov.org/news/ocean-recoveryalliance-news/boom-or-bust-the-future-of-fish-in-the-south-china-sea.html

Svarstad, H., Benjaminsen, T. A. \& Overå, R. (2018). Power theories in political ecology. Journal of Political Ecology, 25(1), 350-363.

Trinidad, A.C., Albert, J., Palma, J., Matillano, M., Boso, D., Gaudiano, J. P. \& Manul, J. (2014). Fisheries value retention in the coral triangle for highly traded commodities. Manila: Asian Development Bank. In Economics of fisheries and aquaculture in the coral triangle, Asian Development Bank, Manila, 2014, pp. 107-140.

UN Comtrade Database. (2018). (https://comtrade.un.org/).

Villasante, S., Rodríguez-González, D., Antelo, M., Rivero-Rodríguez, S., de Santiago, J. A. \& Macho, G. (2013). All fish for China? Ambio, 42(8), 923-936.

Zhan, S., Zhang, H. \& He, D. (2018). China's flexible overseas food strategy: Food trade and agricultural investment between Southeast Asia and China in 1990-2015.

Globalizations, 15(5), 702-721.

Zhang, H. (2016). Chinese fishermen in disputed waters: Not quite a 'people's war'. Marine Policy, 68, 65-73.

Zhang, H. \& Bateman, S. (2017). Fishing militia, the securitization of fishery and the South China Sea dispute. Contemporary Southeast Asia: A Journal of International and Strategic Affairs, 39(2), 288-314.

Zhang, H. (2018a). Fisheries cooperation in the South China Sea: Evaluating the options. Marine Policy, 89, 67-76.

Zhang, H. (2018b) Security implications of China's rising appetite for seafood. ANALYSIS. Retrieved from https://www.asiaglobalonline.hku.hk/security-china-seafood-fish/

\section{Acknowledgements}

The research for this article was supported by the Australian Research Council Discovery Program (DP140101055 and DP180100965).

\section{Author Biographical Detail}

Dr. Michael Fabinyi is an Associate Professor at the University of Technology Sydney (UTS). His research interests include the social aspects of marine resource use, trade and governance; the role of China in global fisheries; and coastal livelihoods in Southeast Asia. 
